UDC 35.07: 351.86: 355.45

DOI https://doi.org/10.32849/2663-5313/2021.7.15

\title{
Denys Chyzhov,
}

PhD in Law, Senior Research Fellow, Scientific Research Institute of State Building and Local Government of National Academy of Law Sciences of Ukraine, 80, Chernyshevskogo street, Kharkiv, Ukraine, postal code 61002, denys chyzhov@ukr.net

ORCID: orcid.org/0000-0002-4843-0670

Chyzhov, Denys (2021). Organizational and legal support of human rights and freedoms in the national security of Ukraine. Entrepreneurship, Economy and Law, 7, 98-103.

\section{ORGANIZATIONAL AND LEGAL SUPPORT OF HUMAN RIGHTS AND FREEDOMS IN THE NATIONAL SECURITY OF UKRAINE}

\begin{abstract}
The purpose is to analyse the organizational and legal support of human rights and freedoms in the national security of Ukraine. Research methods. The paper is executed by applying the general research and special methods of scientific cognition. The key methods of the article are dialectical, comparative and modeling methods, which helped to identify and form appropriate approaches. Results. The article determines that ensuring the security of man and citizen, society and the state is undoubtedly the top priority of the modern state. Any democratic, legal, social state recognizes security in its country as a priority. At the same time, security must be ensured both for each person and on a nationwide scale. It was shown that these relations have a two-way connection: human rights violations not only breach legal prohibitions, the human position in society, but also negatively affect other elements of the national security system: a society in which violations of the rights and freedoms of its members to consider reliable, responsible, civil; a state in which the rights of its citizens are violated cannot be considered law-governed and democratic, etc. The system of organizational and legal support of human rights and freedoms in the national security of Ukraine is represented by a set of hierarchically organized sources of normative regulation. A four-level system of sources is outlined in the article. Conclusions. It is concluded that human rights and freedoms today are the most important value which the state must ensure in all spheres of life, including security. The state cannot be otherwise considered legal and one which can participate in international aggression. The insurance of human rights and freedoms in the field of national security of Ukraine should begin with organizational and legal support, i. e., the creation of a reliable legal foundation for state activities to enshrine human rights and freedoms in the field of national security of Ukraine.
\end{abstract}

Key words: rights and freedoms, enforcement of rights, national security, organizational and legal support, rule of law state, obligations of the state.

\section{Introduction}

Ukraine is a sovereign and independent state, which found itself in a forced adversary resisting Russian aggression. Currently, the Russian Federation remains a source of a protracted threat to Ukraine's national security, stability and international democratic values worldwide. This provides rationale for introducing an effective strategy aimed at ensuring the termination of hostilities and the restoration of the territorial integrity of Ukraine within its internationally recognized state border based on international law (Vseukrainskyi Forum, 2021). The mentioned provisions are available on the official website of the All-Ukrainian Forum "Ukraine 30", part of which was devoted to the country's security issues (May 11-13). In this context, our country needs constant updating and enhancement in terms of legal and organizational support of human rights and freedoms in the sphere of Ukrainian national security. The relevance of the chosen course is evidenced by the holding of the All-Ukrainian Forum "Ukraine 30" and consideration of fundamental issues related to ensuring the country's security. In light of this, the author believes that such issue under study as organizational and legal support of human rights and freedoms in the sphere of the national security of Ukraine is hot-button and needs a new scientific enquiry.

2. Analysis of recent research and publications

It should be noted that there are no specialized studies of organizational and legal support of human rights and freedoms in the sphere of national security of Ukraine. Some aspects of the subject were studied by various 
scientists. For instance, V. A. Lipkan analyzed the theoretical and methodological principles of management in the sphere of national security of Ukraine (Lipkan, 2005). H. A. Honcharenko examined the issue of security management in Ukraine (Honcharenko, 2020). Legal foundations of military security of Ukraine are investigated in E. L. Streltsov's monograph (Streltsov, 2016). O. P. Dzioban explored various aspects in numerous works: in his monograph, he undertook an analysis of national security in the framework of social transformations (research and provision methodology) (Dzioban, 2006), looked at national security through worldviews and theoretical and methodological principles (Dzioban, 2021), philosophical and legal aspects human rights and national security (Dzioban, Zhdanenko, 2020 ). One should pay attention to the International Conference on the Constitution Day of Ukraine "Human Rights and National Security: the role of the constitutional jurisdiction" took place, which was attended by the Chairman and judges of the Constitutional Court of Ukraine, the retired judges of the Constitutional Court of Ukraine, representatives of state authorities, heads and judicial bodies of constitutional jurisdiction of foreign countries, representatives of the diplomatic corps and international organizations, as well as national and foreign scholars (Prava liudyny $\mathrm{i}$ natsionalna bezpeka, 2021).

The main purpose of this research is to analyze the organizational and legal support of human rights and freedoms in the national security of Ukraine.

\section{Research results}

The top priority of the modern state is undeniably to ensure the security of a man and citizen, society and the country. Any democratic, legal, social state recognizes security in its country as a priority. At the same time, security must be ensured both for each individual at the national level. We believe that these relations are bidirectional ones: human rights violations not only infringe legal limitations, the human position in society, but also negatively impact other elements of the national security system: a society in which the rights and freedoms violations can not be considered reliable, responsible, civil; a state in which the rights of its citizens are violated cannot be considered legal, democratic, etc. When it comes to ensuring the rights and freedoms of a man and citizen, this is the most important element in the system of national security.

To comfirm this thesis, the author uses the provisions of the Fundamental Law of Ukraine as an example. Thus, Article 3 of the Constitution of Ukraine stipulates that "an individual, his life and health, honour and dignity, inviolability and security shall be recognised in Ukraine as the highest social value. Human rights and freedoms and their guarantees outline the content and direction of the state. Human rights and freedoms, and guarantees thereof shall determine the essence and course of activities of the State. The State shall be responsible to the individual for its activities. Affirming and ensuring human rights and freedoms shall be the main duty of the State" (Konstytutsia Ukrainy, 1996).

A noteworthy scientific analogy of the two-way connection between state security and human rights is provided by W. Burke-White. He formulated three wellfounded hypotheses linking the degree of human rights violations with the manifestations of interstate aggression, namely: 1) states that systematically violate the rights and freedoms of their citizens are highly likely to participate in international aggression; 2) states in which the rights and freedoms of man and citizen are protected sufficiently and well, are unlikely to take part in international aggression; 3 ) states in which the rights and freedoms of man and citizen are respected may be involved in international intervention only on the basis of international law and in order to protect the rights and freedoms of citizens from violations by their own state (BurkeWhite, 2004). Therefore, one may conclude that human rights and freedoms today are the most important value that the state must ensure in all spheres of life, including security. The state cannot be otherwise considered legal and potentially be regarded to be able to take part in international aggression.

The state should strive to ensure national security, which the legislator offers to understand as "the protection of state sovereignty, territorial integrity, democratic constitutional order and other national interests of Ukraine from real and potential threats". Moreover, "the national interests of Ukraine are vital interests of man, society and the state, the implementation of which guarantees the state sovereignty of Ukraine, its progressive democratic development, as well as safe living conditions and welfare of its citizens" (Pro natsionalnu bezpeku Ukrainy, 2018). From the auhtor's point of view, the essence of "vital human interests" is not limited to "interests". Primarily, this referes to human rights and freedoms and then, the objects of his interests. Moreover, it seems extremely difficult to distinguish vital interests from others: each person has his original list of vital interests. Besides, under different 
circumstances, the priority of interests will be different. According to O. P. Dzioban and S. B. Zhdanenko, the most crucial factors that determine the overall level of society development, as well as the national security of the individual state, are such characteristics as "human freedom", "human development" and, as a consequence, "human rights" (Dzioban, Zhdanenko, 2020, p. 10). This means that the rights and freedoms of the individual are the highest state priority and, respectively, the object of national security. Thus, there is every reason to assume that ensuring the rights and freedoms of the individual is a kind of national security criterion, the level of the country democracy.

It is worth mentionning that the United Nations Organization stipulates that "the protection of human rights in any country should be carried out in the following areas of its security: economic security, food security; health safety; environmental safety; personal security; public safety; political security". It stands to reason that all these areas of security can be attributed to national security. It is highly unlikely that national security is ensured at the appropriate level in a country where the environmental security of the population or the personal security of every citizen is not guaranteed, etc.

From our standpoint, ensuring human rights and freedoms in the sphere of national security of Ukraine should begin with organizational and legal support, that is creating a reliable legal foundation for state activities to ensure human rights and freedoms in the field of national security of Ukraine.

V. O. Antonov considers the system of national security of Ukraine as one that intrinsically combines a number of subsystems and elements, which is due to the objective laws of human development, society and the state and is considered an open dynamic system in the set of its most important internal and external relationships (Antonov, 2017, p. 219). We hold that a separate subsystem that is part of the national security system of Ukraine basically is the system of its organizational and legal support, which we propose to understand a set of interconnected elements that together ensure the state of protection of the main objects of national security of our state.

The Law of Ukraine "On National Security of Ukraine" stipulates that "the legal basis of state policy in the spheres of national security and defense is the Constitution of Ukraine, as well as other laws of Ukraine, international treaties approved by the Verkhovna Rada of Ukraine and issued in compliance with the Constitution and laws of Ukraine, other normative legal acts" (Article 2). Thus, the legislator defined the hierarchy of state policy legal regulation sources in the spheres of national security and defense. We believe that this approach can undoubtedly be implemented to determine the organizational and legal support of human rights and freedoms in the sphere of national security of Ukraine. It should be noted though that traditionally the hierarchy of sources of legal regulation of any relations in Ukraine is determined as follows: the Constitution of Ukraine, international treaties approved by the Verkhovna Rada of Ukraine, laws of Ukraine, bylaws, and so on and so forth. Therefore, we propose to explicate the organizational and legal support of human rights and freedoms in the field of national security of Ukraine using the latter approach.

First, organizational and legal support takes place at the level of the Constitution of Ukraine. We believe that the Constitution enshrines rights and freedoms related to the sphere of national security, which are not directly related to this sphere, but regulate it. In fact they basically include: the inalienable human right to life; the right to respect for human dignity; the right to liberty and security of person; inviolability of the home; secrecy of correspondence, telephone conversations, telegraph and other correspondence; freedom of movement, free choice of place of residence, the right to leave the territory of Ukraine freely, except for restrictions established by law; the right to freedom of thought and speech, to free expression of one's views and beliefs; the right to freedom of thought and religion; the right to freedom of association in political parties and public organizations to exercise and protect their rights and freedoms and to satisfy political, economic, social, cultural and other interests, except for restrictions established by law in the interests of national security and public order, population health care or protection of the rights and freedoms of others; the right to participate in the state administration, in allUkrainian and local referendums, to freely elect and be elected to bodies of state power and bodies of local self-government; the right to peaceful assemblies, without weapons and to hold meetings, rallies, marches and demonstrations, the holding of which shall be notified in advance to the executive authorities or local selfgovernment bodies; the right to send individual or collective written appeals or personally apply to public authorities, local governments and officials of these bodies, which are obliged to consider the appeal and give a grounded response within the relevant time frame, etc. (Konstytutsia Ukrainy, 1996). Ensuring these human and civil rights and freedoms is the basis 
of their organizational and legal support and will maintain the national security of Ukraine.

$$
\text { Second, the international }
$$
treaties and international obligations of our state comprise the following element in the organizational and legal support of human rights and freedoms in the field of national security of Ukraine. They are as follows: the Universal Declaration of Human Rights of 1948, the Convention for the Protection of Human Rights and Fundamental Freedoms of 1950, the International Covenant on Economic, Social and Cultural Rights of 1966, the International Covenant on Civil and Political Rights of 1966. These regulations stipulate fundamental human rights, which are guaranteed at the international level and must be ensured by each member state of these international instruments.

Third, the organizational and legal support of human rights and freedoms in the field of national security of Ukraine is enshrined by the laws of Ukraine, in particular the Law of Ukraine "On National Security of Ukraine", which lays the foundations and principles of national security and defense, goals and basic principles of public policy that will guarantee society and every citizen protection from threats. In additition, the following laws of Ukraine can be referred to this link of normative-legal provision: "On the principles of domestic and foreign policy", "On public associations", etc.

Fourth, the bylaws which include the National Security Strategy of Ukraine of September 14, 2020, which was approved by the Decision of the National Security and Defense Council of Ukraine and approved by the President of Ukraine. It is worth noting that the National Security Strategy of Ukraine is entitled "Human Security - Country Security". This reaffirms the twofold link between the security of the individual and the security of the whole country. As defined by the Strategy, the priorities of Ukraine's national interests and national security are: independence and state sovereignty; restoration of territorial integrity within the internationally recognized state border of Ukraine; social development, first of all development of human capital; protection of the rights, freedoms and legitimate interests of the citizens of Ukraine; European and Euro-Atlantic integration (Stratehiya natsionalnoi bezpeky Ukrainy, 2020). Thus, at the level of relevant regulations, the protection of the rights, freedoms and legitimate interests of the citizens of Ukraine is a priority of national interests, and human security is an integral part of the country's security.

Moreover, regulatory and legal support includes the Resolution of the Verkhovna Rada of Ukraine "On the main directions of state policy of Ukraine in the field of environmental protection, use of natural resources and environmental safety" of 1998 (Postanova Verkhovnoi Rady Ukrainy, 1998); the Decision of the National Security and Defense Council of Ukraine of March 23, 2021 "On challenges and threats to national security of Ukraine in the environmental sphere and priority measures to neutralize them" (Rishennia Rady natsionalnoii bezpeky i oborony Ukrainy, 2021) and other regulations. Given the limited scope of the present study, we will dwell on these regulations.

\section{Conclusions}

The article determines that the top priority of the modern state is ensuring the security of a man and citizen, society and the state. Any democratic, legal, social state recognizes security in its country as a priority. At the same time, security must be ensured for each person as well as nationwide. The author proves that these relations have a two-way connection: human rights violations not only breach legal prohibitions, the human position in society, but also have a negative impact on other elements of the national security system a society in which the rights and freedoms of its members are violated cannot be considered reliable, responsible, civil; a state in which the rights of its citizens are infringed cannot be considered legal, democratic, etc. It all starts with ensuring the rights and freedoms of man and citizen and this is the most crucial element in the system of national security. It is concluded that human rights and freedoms today are the indispensable values that the state must ensure in all spheres of life, including security. The state cannot be otherwise considered legal and virtually able to participate in international aggression.

In the author's opinion, the protection of human rights and freedoms in the field of national security of Ukraine should begin with organizational and legal support, i.e., creation of a reliable legal foundation for state activities to ensure human rights and freedoms in the field of national security of Ukraine. We believe that a separate subsystem, that is part of the national security system of Ukraine, is the system of its organizational and legal support, which we propose to understand a set of interconnected elements that together ensure the state of protection of the main objects of national security of our state. The system of organizational and legal support of human rights and freedoms in the sphere of national security of Ukraine is represented by a set of hierarchically organized sources of normative regulation. In the article we outline a fourlevel system of sources. First, organizational 
and legal support takes place at the level of the Constitution of Ukraine, which enshrines rights and freedoms relating to national security. Further, in the field of national security of Ukraine, there are relevant international treaties and international obligations. Third, there are the relevant laws of Ukraine, as follows: "On National Security of Ukraine", "On the Principles of Domestic and Foreign Policy", "On Public Associations", etc. Fourth, there are the bylaws, such as National Security Strategy of Ukraine, Resolution of the Verkhovna Rada of Ukraine "On the Main Directions of the State Policy of Ukraine in the Field of Environmental Protection, Use of Natural Resources and Ensuring Environmental Security", as well as Decisions of the National Security and Defense Council of Ukraine "On Challenges and Threats to National Security of Ukraine in the Environmental Sphere and Priority Measures for Their Neutralization" and other regulations.

\section{References:}

Antonov, V.O. (2017). Konstytutsiyno-pravovi zasady natsionalnoi bezpeky Ukrainy: monohrafiia [Constitutional-legal principles of national security of Ukraine: monograph] / ed. by Yu.S. Shemshuchenko. Kyiv: TALKOM (in Ukrainian).

Burke-White, W.W. (2004). Human Rights and National Security: The Strategic Correlation. Harvard Human Rights Journal, no. 17, pp. 254. Retrieved from: https://www.law.upenn.edu/cf/faculty/wburkewh/ workingpapers/.pdf (in English).

Dzioban, O.P. (2006). Natsionalna bezpeka v umovakh sotsialnykh transformatsiy (metodolohia doslidzhennia ta zabezpechennia): monohrafiia [National security in terms of social transformations (research methodology and support): monograph]. Kharkiv: Konstanta (in Ukrainian).

Dzioban, O.P. (ed.). (2021). Natsionalna bezpeka: svitohliadni ta teoretyko-metodolohichni zasady: monohrafiia [National security: worldview and theoretical and methodological principles: monograph]. Kharkiv: Pravo (in Ukrainian).

Dzioban, O.P., Zhdanenko, S.B. (2020). Prava liudyny i natsionalna bezpeka: filosofsko-pravovi aspekty vzaiemozviazku [Human rights and national security: philosophical and legal aspects of the relationship]. Informatsiya i pravo: naukovyi zhurnal, no. 2, pp. 9-22 (in Ukrainian).

Honcharenko, H.A. (2020). Upravlinnia sektorom bezpeky Ukrainy: problemy teorii ta praktyky [Management of the security sector of Ukraine: problems of theory and practice]. Kharkiv: Pravo (in Ukrainian).

Konstytutsia Ukrainy [The Constitution of Ukraine] (1996). Vidomosti Verkhovnoi Rady Ukrainy, no. 30, art. 141 (in Ukrainian).

Lipkan, V.A. (2005). Teoretyko-metodolohichni zasady upravlinnia u sferi natsionalnoi bezpeky Ukrainy: monohrafiia [Theoretical and methodological principles of management in the field of national security of Ukraine: monograph]. Kyiv: Tekst (in Ukrainian).

Postanova Verkhovnoi Rady Ukrainy "Pro Osnovni napryamy derzhavnoi polityky Ukrainy u haluzi okhorony dovkillia, vykorystannia pryrodnykh resursiv ta zabezpechennia ekolohichnoi bezpeky" [Resolution of the Verkhovna Rada of Ukraine "On the Main Directions of the State Policy of Ukraine in the Field of Environmental Protection, Use of Natural Resources and Ensuring Environmental Safety"] (1998). Vidomosti Verkhovnoi Rady Ukrainy, no. 38-39, art. 248 (in Ukrainian).

Prava liudyny i natsionalna bezpeka: rol orhanu konstytutsiinoi yurysdyktsii: Mizhnarodna konferentsia z nahody Dnia Konstytutsii Ukrainy [Human rights and national security: the role of the body of constitutional jurisdiction: International Conference on the occasion of the Constitution Day of Ukraine] (2019). Retrieved from: https://ccu.gov.ua/novyna/prava-lyudyny-i-nacionalna-bezpeka-rol-organu-konstytuciynoyiyurysdykciyi-mizhnarodna-1 (in Ukrainian).

Rishennia Rady natsionalnoii bezpeky i oborony Ukrainy "Pro vyklyky i zahrozy natsionalnii bezpetsi Ukrainy v ekolohichnii sferi ta pershocherhovi zakhody shchodo yikh neitralizatsii" vid 23 bereznia $2021 \mathrm{r}$. [Decision of the National Security and Defense Council of Ukraine "On challenges and threats to Ukraine's national security in the environmental sphere and priority measures to neutralize them" dated March 23, 2021] (2021). Uriadovyi kurier, no. 57 (in Ukrainian).

Stratehiya natsionalnoi bezpeky Ukrainy vid 14 veresnia 2020 r. [National Security Strategy of Ukraine of September 14, 2020] (2020). Retrieved from: https://www.president.gov.ua/documents/3922020-35037 (in Ukrainian).

Streltsov, E.L. et al. (2016). Pravovi osnovy voiennoi bezpeky Ukrainy: monohrafia [Legal foundations of military security of Ukraine: monograph]. Lviv: Natsionalna akademia sukhoputnykh viisk (in Ukrainian).

Vseukrainskyi Forum "Ukraina 30": Bezpeka krainy (11-13 travnia 2021 r.) [All-Ukrainian Forum "Ukraine 30": Security of the country (May 11-13, 2021)] (2021). Retrieved from: https://ukraine30.com/ national_security (in Ukrainian).

Zakon Ukrainy "Pro natsionalnu bezpeku Ukrainy" [Law of Ukraine "On national security of Ukraine"] (2018). Vidomosti Verkhovnoi Rady Ukrainy, no. 31, art. 241 (in Ukrainian). 


\section{Денис Чижов,}

кандидат юридичних наук, старший науковий співробітник, Науково-дослідний інститут державного будівниитва та місиевого самоврядування Національної академій правових наук України, вул. Чернишевська, 80, Харків, Україна, індекс 61002, denys_chyzhov@ukr.net

ORCID: orcid.org/0000-0002-4843-0670

\section{ОРГАНІЗАЦІЙНО-ПРАВОВЕ ЗАБЕЗПЕЧЕННЯ ПРАВ ТА СВОБОД ЛЮДИНИ У СФЕРІ НАЦІОНАЛЬНОЇ БЕЗПЕКИ УКРАЇНИ}

Анотація. Метою статmі є аналіз організаційно-правового забезпечення прав і свобод людини у сфері національної безпеки України. Методи дослідження. Стаття виконана із застосуванням загальнонаукових та спеціальних методів наукового пізнання. Провідними методами дослідження були діалектичний, компаративний і метод моделювання, які дали змогу виокремити та сформувати відповідні підходи. Результати. У статті визначено, що забезпечення безпеки людини та громадянина, суспільства та загалом держави є, безперечно, найголовнішим пріоритетом сучасної держави. Будь-яка демократична, правова, соціальна держава визнає пріоритетною безпеку у своїй країні. При цьому безпека має забезпечуватися як щодо кожної особи, так і на загальнодержавному рівні. Автором доведено, що ці відносини мають двосторонній зв'язок: порушення прав людини не лише порушує законодавчі заборони, становище людини в суспільстві, а й негативно впливає на інші елементи системи національної безпеки. Так, суспільство, у якому відбуваються порушення прав і свобод його учасників, не можна вважати надійним, відповідальним, громадянським; державу, у якій відбувається порушення прав їі громадян, не можна вважати правовою, демократичною тощо. Констатовано, що окремою підсистемою, яка входить до системи національної безпеки України, є система їі організаційно-правового забезпечення, під якою запропоновано розуміти комплекс взаємопов'язаних елементів, що в сукупності забезпечують стан захищеності основних об'єктів національної безпеки нашої держави. Система організаційно-правового забезпечення прав і свобод людини у сфері національної безпеки України представлена комплексом ієрархічно впорядкованих джерел нормативного регулювання. У статті визначено чотирирівневу систему таких джерел. Висновки. Зроблено висновок про те, що права і свободи людини сьогодні становлять найважливішу цінність, яку держава має забезпечувати в усіх сферах життєдіяльності, зокрема й у сфеpi безпеки. В іншому разі держава не може вважатися правовою та потенційно сприйматиметься як така, що може брати участь у міжнародній агресії. Забезпечення прав і свобод людини у сфері національної безпеки України має розпочинатися з організаційно-правового забезпечення, тобто створення надійного правового фундаменту для державної діяльності щодо забезпечення прав та свобод людини у сфері національної безпеки України.

Ключові слова: права та свободи, забезпечення прав, національна безпека, організаційноправове забезпечення, правова держава, зобов'язання держави.

The article was submitted 14.07.2021

The article was revised 03.08.2021

The article was accepted 25.08.2021 